\title{
Analysis on the Relationship Between Pledge of Stock Right and Shareholders' Preemptive Right
}

\author{
Fuling Ding ${ }^{1}$ \\ ${ }^{1}$ Sichuan University, Chengdu, Sichuan Province, China
}

Keywords: Pledge Of Stock Right, Shareholders' Preemptive Right, Stock Right Transfer, Right Of Revocation.

\begin{abstract}
The implementation of pledge of stock right may produce results of equity transfer. But existing laws and regulations do not mention whether shareholders can exercise their preemptive right in the process of realizing pledge of stock right, or how to exercise their preemptive right. This paper argues that, in the establishment stage of pledge of stock right, companies do not need to comply with procedural provisions on equity transfer in theCorporation Law,and the preemptive right of shareholders is not involved; while in the implementation phase, companies should respect the preemptive right of shareholders. Institutional defects still exist in the limitation of shareholders' preemptive right, the definition of equal conditions and the effectiveness of contracts against the preemptive right of shareholders, and it is necessary to improve them through procedure and system design.
\end{abstract}

\section{Introduction}

Pledge of stock right is one kind of pledge of rights. It has its own particularities compared with pledge of movables and common pledge of rights. The subjects of pledge of stock right include limited liability companies andincorporated companies. The circulation and realization of pledge of stock right in limited liability companies are different from the pledge of stock right in incorporated companies. The implementation ofpledge of stock right may produce results of equity transfer.But the Guarantee Law, Property LawandCorporation Lawdo not mention whether shareholders can exercise their preemptive rightin the process of realizing pledge of stock right, or how can these shareholders exercise their preemptive right.Today, more and more companies are using the pledge of stock right as a financing method. If there is no clear legal provision on this issue, disputes on shareholders'pledge of stock right in limited liability companies will occur. Thus, it is necessary to straighten out the relationship between pledge of stock right and shareholders' preemptive right, and perfect the system design.

\section{Relationship Between Pledge of Stock Right and Shareholders' Preemptive Right}

The subjects of pledge of stock right. The subjects of pledge of stock right are directly related to the influence degree of pledge of stock right on shareholders' preemptive right. Therefore, in order to explore the relationship between the two parties, it is necessary to clear the subjects of pledge of stock right firstly. In accordance with provisions in the seventy-fifth article of the Guarantee Law, the subjects of pledge of stock right are "legally transferable shares and stocks". Property Lawand Corporation Lawdefine the objects of transfer and pledge as "stock right". Stock and stock rights are two different concepts. Stock right is the inner value connotation of stocks, while stocks are the existing form of stock rights. Thus, it is more scientific to unify the subjects of pledge as "stock rights".

As a special right, stock right has both property and personality. There are different views on whether pledge of stock right is purely property interests and rights, or personal interests and rights plus property interests and rights. The author believes that, stock right is a kind of special right which 
integrates the right of self interest and the right of common interest. First of all, the establishment of pledge of stock right is different from the implementation of pledge of stock right. Although the pledge of stock right and its implementation can give rise to the transfer of shares, the establishment of pledge can not immediately change the ownership of stock right. Pledgee cannot own stock right directly through the pledge of stock right. Pledgee enjoys the pledge of right, rather than the ownership of stock right. Secondly, the purpose of pledge is to protect pledgee. If the pledge is limited to property rights, it will be difficult and inconvenient to realize. Therefore, it is not appropriate to limit the pledge of stock right to property rights. The subjects of the pledge should include all powers and functions of stock right.

The relationship between the establishment stage of pledge of stock right and shareholders' preemptive right. Scholars have different views onwhether the establishment of pledge should respect shareholders' preemptive right, which is depending on whether the establishment of pledge shouldaccords with procedural provisions on transfer of shares in limited liability companies in corporate laws. Some people holds that, in accordance with provisions in theGuarantee Law, procedural provisions on transfer of shares should apply to the pledge of stock right. Others believe that the contract of pledge of stock right and the establishment of stock right pledge do not need to comply with procedural provisions in the Corporation Law.The author believes that, in the pledge establishment stage, companies do not need to comply with procedural provisions on equity transfer in theCorporation Law.There are three reasons.First, in the pledge establishment stage, the ownership of stock rights still belongs to pledgors.Second,the characters based on shareholders in limited liability companies are not affected by the pledge of stock right.The realization of equity transfer is just a kind of possibility and expectation interests; it does not change the actual structure of shareholders. Third,if limited liabilitycompanies need to comply with procedural provisionsin this stage,the liquidity of stock rights will reduce,the efficiency and freedom of trade will be damaged, and it will become more difficult for limited liability companies to broaden their financing channels.

Since there is no need to comply with procedural provisions of transfer shares, it does not involve the actual changes of stock rights, nor the issue of shareholders' preemptive right.

The relationship between theimplementation phase of pledge of stock right and shareholders' preemptive right. There are two kinds of situations in the liquidation period of creditor's rights in the pledge of stock right. One situation is that, in accordance with article 219 of the Property Law, the debtor or pledgor pay off debts in time, and the pledgee shall return the pledge of stock right. Another is that, the debtor fails to pay off debts, or the situation of execution of right of pledged bills occurs, the pledgee will have priority of getting compensation from the pledge of stock. In this case, the realization of pledge of stock right is not only related to the interests of creditors, but also related to the third party which has specific interest relations (the interests of other shareholders).

Some people believe that, the realization of pledge does not have any adverse effects on the trust and cooperation between shareholders of a company. From my point of view, this opinion is worth discussing. In accordance with article 219 of the Property Law, chattel pledge right can be used to achieve the realization of pledge of stock rights. The pledgee and pledgor can make an agreement to discount, auction or sale properties pledged. All of discount, auction and sale will have impacts on the ownership of equity. Therefore, the author believes that in the implementation phase of pledge of stock right, companies need to comply with procedural provisions on equity transfer in the Corporation Law, including the preemptive right of shareholders.

First of all, shareholders' preemptive right is a legal right granted by the law; respecting shareholders' preemptive right will not affect the substantive rights of pledgee. Secondly, in this stage, if shareholders' preemptive right is notrealized, some shareholders may transfer equities in the name of pledge, which will damage the closure and characters based on shareholders of the limited liability company. After all, the equity of a limited liability company is different from that of a listed company and an unlisted company; the stock rights of listed and unlisted companies can be freely transferred in the secondary market and circulated outside the company. In addition, the shareholders' preemptive right will not affect the realization of security value and exchange value of the equity. Finally, the 
price competition between the pledgee and shareholders will help to improve the liquidity of equity, reflect the value of equity better, and guarantee the repayment rate of pledgee.

The relationship between the enforcement of pledge of stock right and the preemptive right of shareholders. On the basis of creditors' application and expired legal instruments, the court can enforce the person subject to enforcement to transfer stock rights. According to the seventy-second article of the Corporation Law, in this process, the court needs to notify the company and all other shareholders; these shareholders have preemptive right under the same conditions. If a shareholder fails to exercise preemptive right within twenty days from the date of notification, the shareholder will be deemed to give up the preemptive right. In the enforcement process, the law clearly stipulates shareholders' preemptive right, and fully respects the rights of other shareholders.

\section{The Lack of System Which Link the Pledge of Stock Right with Shareholders' Preemptive Right}

The realization of pledge of stock right should respect shareholders' preemptive right. But there's no clear regulations on which shareholders' preemptive rights should be realized in the implementation of pledge of stock right. It is not conducive to the protection of pledgee and other shareholders of limited liability companies.

The time limit for exercising shareholders' preemptive right. When the conditions for the realization of pledge are satisfied, in accordance with the provisions of the Property Law, the pledgee may exercise rights in the form of discount, auction and sale. However, in accordance with the provisions of the Corporation Law, the pledgee need to fulfill obligations of noticing other shareholders of the limited liability company. If a shareholder fails to reply within thirty days from the date of the notice, the shareholder will be deemed to agree with transfer. If more than half of other shareholders do not agree with the transfer, the shareholder who does not agree shall buy the equity interest in the transfer; if the shareholder does not buy, the shareholder will be deemed to agree with transfer. For stock rights which can be transferred according to shareholders, other shareholders have preemptive right to purchase under the same conditions. Although the Corporation Lawstipulates that if a shareholder fails to reply within thirty days from the date of the notice, the shareholder will be deemed to agree with transfer, it does not stipulate The time limit for exercising shareholders' preemptive right. Thus, if other shareholders do not exercise the preemptive right and do not express this clearly, disputes will occur even if the pledgee realizes the pledge.

Criteria for the recognition of equal conditions. The premise of shareholders' preemptive right is "equal conditions". In the implementation stage, the exercise of shareholders' preemptive right also needs to comply with "equal conditions". In different situations, "equal conditions" have different meaning. For instance, "equal conditions" in discount can be the price negotiated by the pledgee and pledgor; in auction, "equal conditions" may become the reserve price of auction. For the same stock right, different pledge implementations may lead to different prices. However, the standards of "equal conditions" are not clearly stipulated, and disputes are easy to occur.

The effectiveness of transferring shares in violation of the preemptive right of shareholders. In the process of implementation, equity transfer contract needs to be signed by the pledgor and the pledgee or the third party. If the contract damages the preemptive right of shareholders, can this contract still takes effect? There are many different opinions. One view is that, the equity transfer contract produces contractual rights, while shareholders' preemptive right is a king of statutory right. Therefore, the equity transfer contract should be invalid if it damages shareholders' preemptive right. The author believes, that if we claim the contract as invalid, the rights and interests of the pledgee are difficult to be guaranteed, which is not conducive to the promotion of transaction security. Other people hold that this contract should be regarded as revocable contract, because the subjects of preemptive rights are shareholders. We cannot make sure whether they will purchase the stock right or not. Thus, the right of revocation shall be given these shareholders, and the implementation the provisions of the right to remove any exclusion period. At present, courts have different opinions about this issue. At the same time, if the right of revocation is exercised, and the interests of the pledgee are affected. There's no clear regulations on how to deal with their losses. 


\section{Suggestions onSystem Which Link the Pledge of Stock Right with Shareholders' Preemptive Right}

Clear the exercise period of preemptive right. In order to balance the interests of the assignor, other shareholders and assignee who does not belong to shareholders of the company, and balance the efficiency of the commercial act and the stability of legal relationship, shareholders should exercise the preemptive right in a reasonable period of time. Shanghai Senior People's Court stipulates this period as 30 days or 1 year in No. [2004]13 Document. It can improve the efficiency and security level of transaction. But the equity transfer of limited liability company belongs to private autonomy, and shareholders' agreement should be fully respected. Thus, shareholders should be allowed to determine a reasonable period of time in the written notice. After this period, if a shareholder still does not exercise preemptive right after the exhortation of pledgor and pledgee, pledgor and pledgee can believe this shareholder has given up the preemptive right.

Defining criteria of "equal conditions". From the literal sense, "equal conditions" have abundant meanings."Equal conditions" are difficult to be clearly defined in laws and regulations. Even if the standards of "equal prices" can be roughly stipulated, the connotation of "equal conditions" cannot be covered. The author believes that "equal conditions" can not be defined as solidified standards; but the defining method and reference factors which affect the definition of "equal conditions" can be stipulated in laws and regulations. For example, Shanghai Senior People's Court includes the legal relationship between shareholders and the assignee, the special agreement and other factors into the definition of "equal conditions" in No. [2004] 13 Document. The value of stock rights of limited liability companies cannot be determined by stock transfer system or public bidding like listed companies or a part of non listed incorporated companies. Therefore, the introduction of professional evaluation institutions has certain positive significance to the determining of stock right value. If we want to define "equal conditions", stock price can be determined firstly; then additional factors should also be included. If a shareholder can accept the transfer price, but does not accept additional "factors", "equal conditions" cannot be established; the shareholder cannot enjoy the preemptive right accordingly.

The effectiveness of transferring shares in violation of the preemptive right of shareholders. The author believes that, the equity transfer contract against the preemptive right of shareholders should be seen as voidable contract. In the implementation stage, if the pledgor fails to exercise the preemptive rights of shareholders, and transfers stock right to the pledgee or the third party, and if other shareholders agree with the transfer conditions, they can request the court to revoke this contract. In the revocation process, other shareholders can also exercise their preemptive right in the premise of "equal conditions". If they do not agree with the transfer conditions, the premise of "equal conditions" shouldn't exist. Other shareholders can not exercise the preemptive right, or request the court to revoke the contract. After the court revoking the equity transfer contract, the property obtained by the shareholder from the equity transfer contract shall be returned to the assignee. If the assignee or the pledgee suffers losses, the pledgor shall bear corresponding civil liabilities of compensation.

For limited liability companies, characters based on shareholders may block the pledge of stock rights, while characters based on capital can promote the pledge of stock rights. Thus, limited liability companies need to find a balance point between the pledge of stock right and the protection of shareholders' interests. Today, the importance of pledge of stock right is becoming more and more prominent. To balance the various interests involved, the legislation should become more detailed and scientific in order to adapt the social and economic development.

\section{References}

[1] J.H. Liu, Modern Corporate Law, second ed., Legal Press China, Beijing, 2011.

[2] J.H. He, J.T. Deng, Contemporary American Law, first ed., Social Sciences Academic Press, Beijing, 2011. 
[3] P. Jiang(Eds.): A New Course on Corporate Law, Legal Press China, Beijing, 1994.

[4] X.J. Kong, Research on New Problems and Interpretations of Civil and Commercial Laws, People's Court Press, Beijing, 1996.

[5] J.W. Lin, Research on Pledge of Stock Right System, Legal Press China, Beijing, 2005.

[6] C. M. Bruner, Corporate Governance in the Common Law World: The Political Foundations of Shareholder Power. Legal Press China, Beijing, 2016.

[7] Y. Liu, Research on Shareholder Rights Protection, Peking University Press, Beijing, 2016.

[8] J.S. Lv, Disposal and Prevention of Equity Disputes: Shareholder Law Parchment, Peking University press, Beijing, 2015.

[9] 110 Legal Advice: On pledge of Stock Right, http://www.110.com/ziliao/article-17335.html

[10] S.H. Zheng, Y. Lu, Whether the Pledge of Stock Right of the Limited Liability Company Should be Approved by Other Shareholders - Interpretation of Article 87 (3) of the Guaranty Law, http://china.findlaw.cn/gongsifalv/gudongquanyi/guquanzhuanrang/gongsiguquanzhuanrang/56467. html 